the price of this type of coal and brings about a shortage of supply for it. The Ministry of Health requires constant tests to be made of the sulphur content of the flue gases, but the difficulty of doing this, even when working to so low a sulphur content as 0.006 grain per cubic foot, was overcome by means of a new recording device. Continuous tests of the sulphur activity in various parts of London since April 1, 1936, prove that the starting of the Fulham Power Station on November 1, 1936, has had no apparent effect on the atmospheric pollution. The pollution varies with the season and with the weather, being large in winter and during cold winds. The two chimneys are built of reinforced concrete and rise $300 \mathrm{ft}$. above ground-level. The gas-washing plant runs on a non-effluent system which is similar to that devised concurrently by Imperial Chemical Industries, Ltd.

\section{Science and Socialism}

THE first of a "Social Science Series" of pamphlets edited by W. P. Dreaper is entitled "The Future of Civilisation and Social Science" (London : E. T. Heron and Co., Ltd. 1s.). In it $\mathrm{Mr}$. Dreaper presents a study of the principles of scientific meliorism based on Jane Hume Clapperton's book published in 1885, in which socialism is defined as concerted aims for social ends, and scientific meliorism may be regarded as a form of socialism under which progress must come through the individual social unit and not by means of social veneer. Scientific meliorism discriminates between benevolence which is beneficial and that which is not, giving no support to charities which injure the independence of the poor, or relieve them of parental responsibility. It opposes the social forces of sympathetic selection which result in the survival of the unfit and seeks to promote intelligent selection which would result in the birth of the fit. It strenuously supports co-operation in industry as a means of progress and harmony of interests, and proper distribution as a means of improving human conditions. Scientific meliorism also advocates a rational treatment of crime, in which vindictiveness has no ultimate place, and calls for a similar rational attitude to such questions as manners, dress, the equality and relations of the sexes, marriage laws, laws of inheritance, etc., the regulation of population in relation to the natural and industrial position of a nation, and Mr. Dreaper briefly discusses the bearing of its principles on the study of international problems.

\section{Developments in Storage Batteries}

DURING last year, there has been a widespread increase in the number and the variety of the applications of batteries for stand-by purposes and emergency lighting. In the annual review number of the Electrician of January 28, Mr. E. C. McKinnon points out that this is partly due to air-raid precautions, which naturally trust to storage batteries for emergency lighting. Manufacturers are using the popular sizes of the starting batteries used in motor- cars for this purpose when circumstances permit. In other cases, alkaline batteries or sealed-in lead-acid accumulators are employed. The vast programme for broadcasting and recording the incidents of the Coronation ceremony and processions was largely dependent upon batteries. Car radio equipment has been applied to police patrol cars and to police patrol pedal-cycles. Many systems of battery-controlled fire alarms have also been installed. There has been a considerable increase in the demand for accumulators for deaf-aid equipment.

VERY small batteries have been developed for use in meteorological balloons. These are made up into low-tension cells weighing $1 \mathrm{oz}$. each, and 60 cell (144 volts) high-tension batteries weighing only $9 \mathrm{oz}$. when complete with electrolyte. There has been a great demand for batteries for auxiliary propulsion of trolley buses. This system is most useful for manœuvring the vehicles at termini or at special points such as football grounds or on the route lines in the event of power supply failure. There has been an increase in the number of electric vehicles in operation last year of 31 per cent. Bakeries, dairies and salvage departments are using large fleets of electric vehicles. Fleets of 100 to 150 electric vehicles are now not uncommon. Air conditioning by the aid of storage batteries has made great progress in India, but the need for it in Great Britain is not large at present. There have been more than a hundred patents in connexion with accumulators applied for last year, but none of them proposes any radical change in design. Special batteries are much used in aeroplanes and submarines. The standardization of accumulators is receiving attention both in Great Britain and internationally.

\section{Journal of Marine Research}

DurnNg the past several years there has been increasing interest in oceanographic research in the United States, which led to the foundation of the Woods Hole Oceanographic Institute and a special department of the University of Washington, both with well-equipped vessels. From these, and the already established laboratories, there has come very real contributions to our knowledge of the oceansthe nature and causes of the current systems on one hand, and, on the other, studies in the varying productivity of the waters in plant and animal life. It is gratifying that Great Britain is now engaging in active co-operation with the Woods Hole Institute in a survey of the fluctuations from year to year in the current system of the north-west Atlantic, for which the Royal Society is now fitting out a vessel. The annual crop of scientific papers dealing with oceanography has grown rapidly. American contributions appear in rather many and diverse journals, both American and European, so the birth in November last of the Journal of Marine Research comes at a time when its growth is likely to be rapid. It is published by the Sears Foundation, Oceanographic Laboratory of Yale University, and its scope includes articles on physical meteorological theory, owing to 